\title{
Nasal and circulating antibody responses to influenza vaccination and their importance in resistance to infection
}

\author{
D. A. J. TYRRELL* \\ M.D., F.R.C.P., F.R.C.Path., F.R.S. \\ D. S. FREESTONE $\dagger$ \\ M.B., B.S , D.L.O. \\ R. A. BUCKLAND* \\ S.R.M.L.T. \\ S. CHINN* \\ B.A. \\ G. C. SCHILD + \\ B.Sc Ph.D. \\ A. N. SLEPUSHKIN $\$$ \\ M.D.

\begin{abstract}
* MRC Clinical Research Centre, Northwich Park Hospital, Harrow, London.
†Wellcome Research Laboratories, Langley Corut, Beckenham, Kent.

$\ddagger$ WHO World Influenza Centre, National Institute for Medical Research, London, NW7.

$\S$ WHO, Geneva, Switzerland.
\end{abstract}

\begin{abstract}
Summary
Small groups of volunteers were inoculated intranasally with live-attenuated, and parenterally with detergent-split-saline or with whole-virus-oil-adjuvant influenza A2/HK (H3N2) vaccines after the prevalence of Hong Kong strains. Antibody titres in nasal secretions and serum were measured by $\mathrm{HI}$, antineuraminidase and neutralization tests. The oil adjuvant vaccine produced large rises in antibodies and the other two vaccines produced small rises. The volunteers given oil adjuvant and live vaccine were both well protected against challenge with a partly attenuated strain. Statistical analysis showed that resistance to infection was predicted best by high titres of antibody in the serum, but the presence of antibody did not seem to explain completely resistance to infection.
\end{abstract}

THERE is evidence that antibodies directed against both haemagglutinin and neuraminidase may confer immunity to experimental animals. The immune status of man can be only partly predicted by haemagglutination inhibition (HI) tests on serum, and it has been shown that secretory antibody either measured by $\mathrm{HI}$ or neutralization (N) also contributes to resistance to infection by a number of respiratory viruses. There is, however, a need to determine whether antineuraminidase (AN) antibody protects man and to estimate the relative importance of circulating and secretory antibody. In order to approach these questions, two studies have been undertaken. The first was performed when influenza A2/Hong Kong (H3N2) was just beginning to circulate in Britain and few of the population had been infected. Volunteers were inoculated with attenuated influenza viruses-about $10^{5}$ or $10^{6} \mathrm{EID}_{50}$. They had previously donated specimens of nasal washings and of serum and after inoculation further specimens were collected for diagnosis by virus isolation and antibody measurement. The results are summarized in Fig. 1 which shows that when the vaccine 'took', it stimulated AN response in the circulation and that the subjects who resisted infection had higher AN titres than those who were infected. The resistance might have been due to a correlation between the presence of the antibody measured and other more protective antibodies. The titres found, however, were not closely correlated with the titres of $\mathrm{HI}$ or AN, either in the washings or in the circulation. Discriminant analysis showed that the titre of $\mathrm{AN}$ in the circulation was the best predictor of resistance to infection.

Further experiments were carried out when the H3H2 serotype had become widespread, and using other types of vaccine, i.e. killed detergent-split $(\mathrm{A} 2 / \mathrm{HK}+\mathrm{B})$ vaccine given subcutaneously in saline and also an $\mathrm{A} 2 / \mathrm{HK}$ oil-adjuvant vaccine. A saline influenza $B$ vaccine was used as a control. The volunteers were not isolated, the numbers were small and some influenza was still prevalent at the time the study began. Nevertheless, it was shown that the volunteers who were challenged 6 weeks after vaccination with partly attenuated influenza $A 2 / \mathrm{HK}$ were better protected by oil adjuvant and live vaccine than they were by the saline vaccine.

It was found that better rises of nasal antibody were evoked by live than by saline vaccine, but otherwise the responses were rather similar. However, the largest rises followed oil adjuvant vaccine, whether measured by $\mathrm{HI}, \mathrm{N}$, or AN, and in both the circulation and the nasal washings. Discriminant analysis was performed again and showed this time that both $\mathrm{AN}$ and $\mathrm{HI}$ in the circulation were moderately good predictors of resistance, and about as good as $\mathrm{N}$, and 

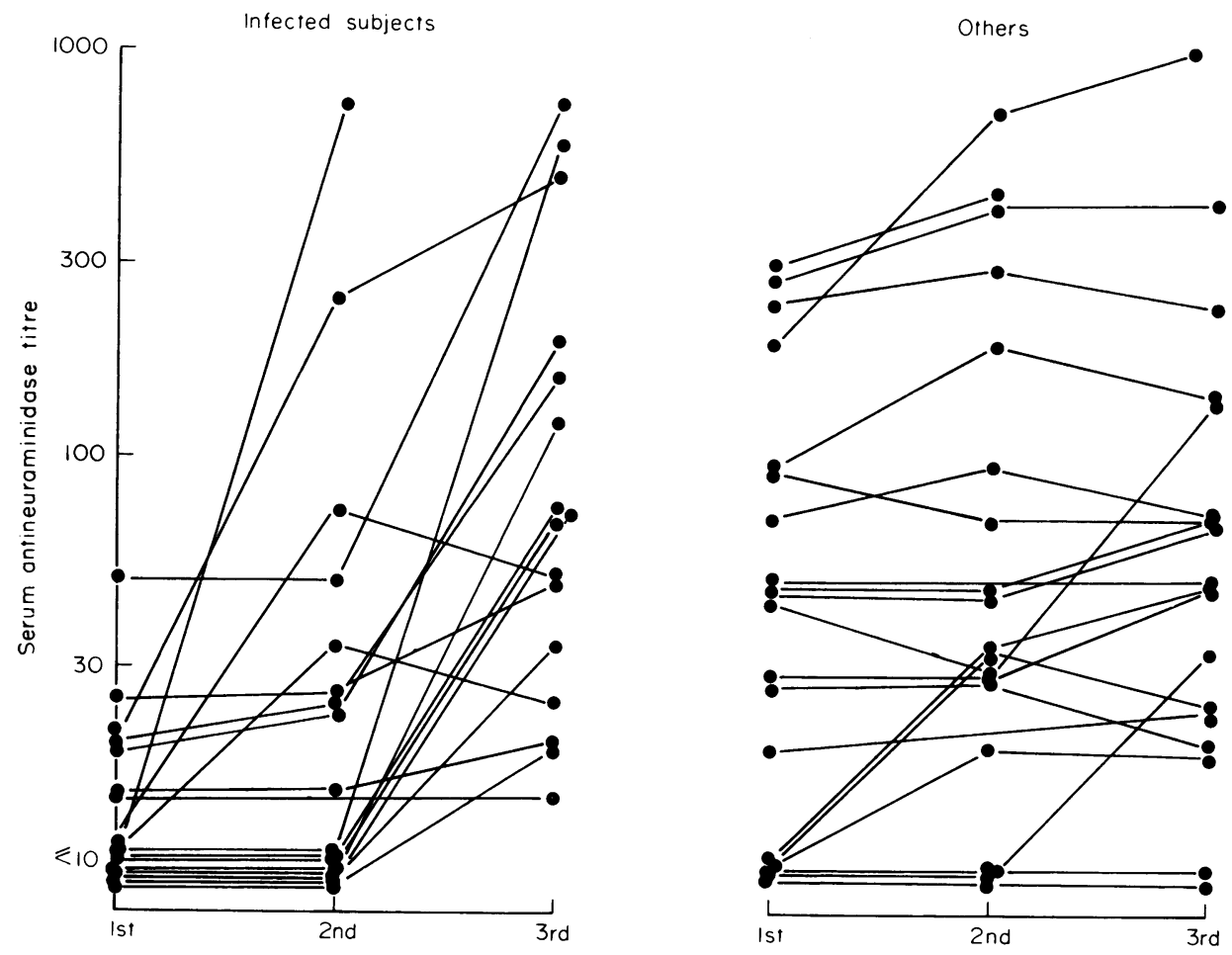

Specimen

FIG. 1. Titres of serum antineuraminidase in volunteers give live influenza H3N2 vaccine. Rising titres occurred mainly in those shown to be infected by other tests and those with high titres were less frequently infected than those with low titres.

TABLE 1. Outcome of challenge with $10^{5} \mathrm{EID}_{50}$ of partly attenuated virus

\begin{tabular}{cccc}
\hline $\begin{array}{c}\text { Vaccine } \\
\text { given }\end{array}$ & $\begin{array}{c}\text { No. of } \\
\text { subjects }\end{array}$ & $\begin{array}{c}\text { No. with } \\
\text { symptoms }\end{array}$ & $\begin{array}{c}\text { No. with laboratory } \\
\text { evidence of infection }\end{array}$ \\
\hline $\begin{array}{c}\text { Live attenuated A2 } \\
\text { nasal }\end{array}$ & 10 & 3 & 2 \\
$\begin{array}{c}\text { Split saline A2 + B } \\
\text { subcutaneous }\end{array}$ & 11 & 7 & 6 \\
$\begin{array}{c}\text { Adjuvant A2 } \\
\text { intramuscular }\end{array}$ & 12 & 3 & 2 \\
$\begin{array}{c}\text { Saline B } \\
\text { subcutaneous }\end{array}$ & 10 & 7 & 7 \\
\hline
\end{tabular}

TABLE 2. Rises in antibody titres during the first 6 weeks after vaccination expressed as a proportion

\begin{tabular}{|c|c|c|c|c|}
\hline Vaccine & Live A & Split A+B & Oil adjuvant $A$ & Unsplit B \\
\hline Nasal HI & $1 \cdot 93 \S$ & $1 \cdot 36 \ddagger$ & $3 \cdot 83 \S$ & 0.05 \\
\hline Serum HI & $0.89 \dagger$ & 0.74 & $6 \cdot 50 \S$ & $1.02 \dagger$ \\
\hline Nasal AN & 0.80 & 0.06 & $2 \cdot 27 \S$ & 0.43 \\
\hline Serum AN & $1 \cdot 39 \dagger$ & $0.97 \dagger$ & $6 \cdot 10 \S$ & 1.05 \\
\hline Nasal $\mathbf{N}$ antibody & 0.35 & 0.89 & 0.96 & 0.00 \\
\hline Serum $\mathrm{N}$ antibody & $1 \cdot 21$ & $2 \cdot 36 \ddagger$ & $17 \cdot 84 \S$ & 0.47 \\
\hline
\end{tabular}

* Each figure in the table is the geometric mean of the ratio of rise in titre to the initial titre for the subjects in the appropriate group, $\dagger, \ddagger$, $\S$ denote that rises were significantly different from zero at 5,1 and $0 \cdot 1 \%$ levels, respectively.

The analysis of variance (using log titres) showed differences between the four groups in rises of titres of nasal and serum $\mathrm{HI}$, and serum $\mathrm{N}$ antibodies (all at $1 \%$ significance level) and of serum $\mathrm{AN}$ (at $5 \%$ significance level); the heterogeneity is almost entirely due to the larger antibody rises in the subjects given oil adjuvant vaccine. 
definitely superior to nasal antibody levels. This may have been in serum, but it seems likely that protection is due to something more than can be measured by these tests or any combination of them.

It seems clear that the presence of AN antibody is correlated with resistance to influenza, and it is possible that this is because the antibody inhibits the spread of virus. Local nasal antibody was a less accurate predictor but no combination of antibody measurements predicted resistance completely. It is possible, therefore, that some other factor, such as non-specific resistance, antibody attached to cells, or cell-mediated immunity, may also play a role.

\section{Acknowledgment}

We wish to thank the editor and publishers of the Journal of Hygiene for permission to reproduce the figure and tables.

\section{References}

Slepushikin, A.N., Schild, G.C., Beare A.S., Chinn, S. \& TYRRELl, D.A.J. (1971) Neuroaminidase and resistance to vaccination with live influenza A2 Hong Kong vaccines. Journal of Hygiene, 69, 571.

Freestone, D.S., Hamilton-Smith, S., Schild, G.C. Buckland, R., Chinn, S. \& Tyrrell, D.A.J. (1972) Antibody responses and resistance to challenge in volunteers vaccinated with live attenuated detergent split and oil adjuvant $\mathrm{A}$ 2/Hong $\mathrm{Kong} / 68\left(\mathrm{H}_{2} \mathrm{~N}_{3}\right)$ influenza vaccines. Journal of Hygiene, 70, 531. 